\title{
Revitalising radical social work
}

\author{
Linda Briskman Western Sydney University, Australia
}

The call to radicalise social work is not new. Some of us are "mature" enough to remember Bailey and Brake's 1975 treatise on the subject. Radical concepts slip and slide around the social work agenda in a semisustainable way. But its enduring presence is masked by terms that fit less controversially into the conservative world order: critical, structural, and transformative among them.

In this comment piece, I argue that we do not need to merely revitalise the radical but to name it, proudly and loudly.

Contemplating the more "progressive" tomes in social work, there is frequently a lament of the times in which we live. Although context and world affairs have differed across the time span in which I have been a social worker, the "Times are Not a-Changin'", to take a liberty with the words of Bob Dylan.

Social workers are expected to be reflective and reflect we must, not only on our own practice in specialisms and fields. We owe it to the profession and those we are tasked to assist to reflect on our work within the current global world order, particularly within western paradigms that permeate many of the contexts in which we are employed, including Australia and Aotearoa New Zealand.

Asylum-seeker politics provide an exemplar for the radical call, politics that are located within pervasive human rights violating policies in Australia and beyond. From my 15 years of work and lament in this sphere, I frame radicalism as a combination of: critical questioning, reflexivity, emotional response and action that pushes boundaries.

To set the scene more broadly, a few words about the troubling world in which we live and work. Although social workers (including myself) are not generally experts in the sphere of international relations, we ought to be critical readers of news. Two contemporary examples at the time I write are Brexit and the rise of Donald Trump. Brexit signals the demise, in the United Kingdom, of internationalism and a return to nation-state thinking, with border security and national "values" taking primacy over human security and human rights. With Donald Trump we have seen a disaffected population attributing blame to migration and even terrorism, and border thinking resonating with pro-Trump supporters within and outside the United States (US).

We are far from experiencing a peaceful world and are increasingly witnessing militaristic responses to human affairs. From the western gaze we observe recent dropping of missiles by the United States on Syria and Afghanistan, and threats directed against North Korea. Social workers are among those who have been outraged by the pushing away of arriving asylum seekers at sea using techniques of warfare. In Australia, Operation Sovereign Borders was used to deter desperate people arriving by boat to seek asylum on Australian soil, and to incarcerate those who had the fortitude to arrive. These maritime asylum seekers were labelled as a threat, particularly those arriving from Muslim majority countries. In the US, we witness Trump's ban on issuing visas to citizens of such countries.

This phenomenon has escalated with a demonisation of Islam and of Muslims beyond asylum seekers. Since the attacks in the US on 11 September 2001, there has been a steady rise in anti-terrorism measures in many countries. Australia has not experienced a terrorist attack on its soil and the increasing raft of legislative
AOTEAROA NEW ZEALAND SOCIAL WORK 29(2), 133-136.

CORRESPONDENCE TO: Linda Briskman L.Briskman@ westernsydney.edu.au 
measures has received harsh rebuke by experts (for example, Williams, 2011), and created suffering with over-zealous policing of Muslim youth (Poynting \& Briskman, in press). Social workers know of trauma and disaffection but are yet to challenge institutionalised Islamophobia in the national narrative and policing practices.

These trends, with the many others that are topics of concern to social work, validate the call for a radical response. From the most micro perspective of practice, social workers are observers of the harms and trauma experienced, not only by people fleeing war and conflict, but those who are marginalised by a master narrative of governments and groups within society who portray those not seen as "integrated" as unworthy. Social workers also encounter individuals who are disaffected, and engaging with a wider political lens can foster a radical analysis.

It would be remiss not to mention Indigenous rights. It can be cautiously stated that, in the Indigenous sphere, social workers have done somewhat better. This is more evident in Aotearoa New Zealand where the Treaty of Waitangi set the foundations for Pākehā/Māori relationships. In Australia, there has been an acknowledgment statement from the Australian Association of Social Workers (2004). But this, alongside other public apologies by government and the welfare sector, has not played out in the wellbeing of Indigenous peoples. Although there have been both rhetorical (and some tangible) gains, in relation to economic, social and cultural rights, Indigenous peoples are faring worse than the rest of the population and in youth and adult imprisonment, the statistics are dire. Although there is more positive engagement, we need to ask Indigenous colleagues whether a radical turn is needed. Should social workers be working hand in hand with the more outspoken Indigenous leaders rather than focusing on policies that fail in their "metrics" such as Close the Gap in Australia? Positioning oneself in this quest is important and constructs of whiteness can provide some leads for ethical engagement.

In 2016, I co-edited with Charlotte Williams and Donna McAuliffe, a special edition of Ethics and Social Welfare on the subject of moral outrage. Extending the idea of outrage, I contend that a component of the reradicalisation project is to be emotional and to push back on the manner in which social work is asked to operate: dispassionate, rule-bound, technocratic. At the practice level, there are systemic obstructions to invoking outrage. Practitioners are often silenced through codes of conduct and fear of loss of funding. As witnesses to suffering that arises from harsh politics, policies and practices, insertion of emotion and radicalisation would go some way toward justice. As Stephane Hessel (2011) asserts in Time for Outrage, when governments cannot be relied upon to defend humanity, it is the role of people, to lead the quest for justice. And going one step further is Nussbaum's (2013, p. 3) assertion that "decent societies need to guard against division and hierarchy by cultivating appropriate sentiments of sympathy and love." Even those of us who work in academia with the freedom it offers experience constraint. One of the editors of this special edition, Heather Fraser (Fraser \& Taylor, 2016), has written about the neoliberal university, a trend that mirrors trends in wider society.

Social work has a particular responsibility, despite imposed limits and self-censoring, to radicalise and to speak out loud. We are not only rhetorically committed to social justice and human rights and to challenging injustices, but we have codified these in ethical statements. But what this commitment means remains elusive. As social work is largely organisational practice, challenge may be merely confined in-house and not to the broader political and social environment. Here we tend to compromise, do "good" often against the odds, fail to see our potential as practice ethnographers (Briskman, 2010) or as human rights social workers and we learn the art of conformity. 
To be a radical social worker means, not only reflective questioning and outrage, but action that may push normative professional boundaries by organising. This requires a radical shift that builds upon activism that may be hidden from the public sphere.

Little has changed since Jim Ife, in 2000, spoke of how many social workers had an interest in international issues by supporting Amnesty International, for example, but in their role as a private citizen. Activist radical social workers today face the same dilemmas as other professions. In the asylum sphere for example, lawyers are told to stick to the law; health workers to dispensing health and teachers to educating the young people. In recent years social workers and others who worked in immigration detention faced legislative barriers. In 2015, the Border Force Act in Australia made it a crime, punishable by two years' imprisonment, for anyone who engages in work for the Department of Immigration to disclose information obtained by them in the course of their work (Bradley, 2015). Although the provisions were repealed for some professions, this was not done for social workers. With a penalty of up to two years' imprisonment, it is little wonder that social workers fear the radical.

\section{Asylum seekers}

I turn to discussing the asylum-seeker situation in Australia, with some overview of the global. It is in this contentious realm that I illustrate the potential for radical engagement. My focus is on asylum seekers (rather than refugees), those who arrive without formal authorisation, a lawful method, and await the bestowing of refugee status. Although Australia is particularly malevolent through mandatorily detaining asylum seekers and transporting them to offshore camps in Nauru and Papua New Guinea, the politics of detention practices are regrettably common.

The Global Detention Project has documented existing facilities (see more at https://www.globaldetentionproject.org/).
Furthermore, ongoing refugee flows have led to a number of countries closing their borders to the fleeing, including erecting fences. Such practices heightened during the Syrian conflict but were not restricted to it. Yet, there are some better news stories, and social workers can encourage those holding anti-asylum-seeker positions to shed their western positioning by asking how it is that other countries, particularly Middle Eastern countries, take more than their fair share of irregular migrants-Jordan, Lebanon and Iran are just three examples.

I am taken with Bill Jordan's (1990) idea of isolated acts of banditry. But the courage of detention workers to speak out against the odds goes beyond banditry to radical action against the power of authorities. One of the issues besetting social work in recent years is the increased employment of social workers within offshore immigration detention centres (Nauru and Papua New Guinea), at the behest of the Australian government. Although the Australian Association of Social Workers has spoken out against mandatory detention and particularly the detention of children, this cannot be seen as radical action but more in line with the majority of asylum-seeker advocates. Social work has not radically grappled with the ethics of social work employment on sites where human rights violations are endemic.

The tenets of radicalism that I refer to above can be readily applied to social workers in immigration detention settings and, through the courage of speaking out, we see a combination of critical questioning of policies and expectations of practice, reflection on how practices are oppositional to social work values and ethics, and emotional responses that invoke a sense of shared humanity. Radical action by Australian social workers was noticeable in the joining with others in a heartfelt statement (which was released confidentially in 2013) about what they had witnessed in Nauru detention. Defiance continued for some, including from medical professionals, after the Border Force Act was proclaimed. I have written (with one social 
worker who has disguised her identity) about what social welfare practice entailed on Nauru (see Briskman \& Doe, 2017).

Rather than whistleblowing being acclaimed as an honourable act, we see media reports that reveal how those who speak out against dominant views are discredited. For social workers, power resides in hierarchies in practice organisations and even challenge at a micro level is not necessarily rewarded. One powerful, yet unexplored, means of speaking out theoretically and practically is to examine one's own practice against "dual loyalty" concepts, which asks for contemplation over where worker loyalties lie: with persons whom we are tasked to assist or with the employing or funding body? The Australian Council of Heads of Schools of Social Work dealt with this dilemma and undertook the People's Inquiry into Detention, which, although seeming radical and even subversive, entered the mainstream by winning an Australian Human Rights Commission Award (Briskman, Latham, \& Goddard, 2008). This one example of pushing boundaries was prompted, not only by social work values and ethics, but revealed a professional stance that refused to collude with human rights abuses.

\section{Conclusion}

In the space I have left, I reiterate the four principles that, for me, encapsulate the heart of radical social work: critical questioning, reflexivity, emotional response and action that pushes boundaries.

I emphasise the need to join up the dots of the local and the global, and for acting for justice in radical ways. The newly formed Social Workers Without Borders (www. socialworkwithoutborders.net) is one way to connect with others with shared concerns across the globe-proudly and loudly.

\section{References}

Australian Association of Social Workers. (2004). Acknowledgment Statement to Aboriginal and Torres Strait Islander People, https://www.aasw.asn.au/ document/item/618
Bailey, R., \& Brake, M. (Eds.). (1975). Radical social work. London, UK: Edward Arnold.

Bradley, M. (2015, July 16). Border Force Act: Why do we need these laws? The Drum. Retrieved from http://www.abc.net.au/news/2015-07-16/bradley-borderforce-act:-why-do-we-need-these-laws/6623376

Briskman, L. (2010). Nation. In I. Shaw, B. Briar-Lawson, J. Orme, \& R. Ruckdeschel (Eds.), Sage handbook of social work research (pp. 351-364). London, UK: Sage Publications.

Briskman, L., \& Doe, J. (2017). Social work in dark places. Social Alternatives, 35(4), 73-79.

Briskman, L., Latham, S., \& Goddard, C. (2008). Human rights overboard: Seeking asylum in Australia. Melbourne, VIC: Scribe.

Fraser, H., \& Taylor, N. (2016). Neoliberalization, universities and the public intellectual. London UK: Palgrave Macmillan.

Hessel, S. (2011). Time for outrage. London, UK: Quartet Books.

Ife, J. (2000, July). Local and global practice: Relocating social work as a human rights profession in the new global order. Eileen Younghusband Memorial Lecture, IFSW/IASSW Biennial Conference, Montreal, Canada.

Jordan, B. (1990). Social work in an unjust society. Hemel Hempstead, UK: Harvester Wheatsheaf.

Poynting, S., \& Briskman, L. (in press). Black flags, plastic swords and other weapons of mass disruption in Australia. In N. Massoumi, T. Mills, H. Aked, \& D. Miller (Eds.), Islamophobia. London, UK: Pluto Press.

McAuliffe, D., Williams, C., \& Briskman, L. (2016). Moral outrage! Social work and social welfare. Ethics and Social Welfare, 10(2), 87-93.

Nussbaum, M. (2013). Political emotions: Why love matters for justice. Cambridge, MA: Belknap Press.

Williams, G. (2011). A decade of Australian anti-terror laws. Melbourne University Law Review, 35(3): 1161-1176. 